\title{
TOURISM AND COMMUNITY. A STUDY OF COMMUNITY BASED TOURISM IN MANDALA WISATA WANARA WANA UBUD
}

\author{
Ida Bagus Putu Puja ${ }^{1}$, Putu Ayu Aryasih ${ }^{2}$ \\ MICE and Event Management ${ }^{1}$, \\ Travel Business Management ${ }^{2}$ \\ Bali Tourism Polytechnic \\ ayuaryasih@ppb.ac.id
}

\begin{abstract}
Community Based Tourism (CBT) is a tourism activity, a community that is owned and operated, and is managed or coordinated at the community level that contributes to community welfare through sustained livelihood support and protects socio-cultural traditions and resources valuable natural and cultural heritage. The analysis was conducted to analyse the results of interviews with local communities and Monkey Forest's management regarding the management of tourist attraction based on community. Data is presented in the form of a description to see the community based tourism in managing Monkey Forest. This qualitative study aims to analyze the community in managing tourism attraction of Mandala Wisata Wanara Ubud (Monkey Forest) through community based tourism.
\end{abstract}

Keywords : Community based tourism, community empowerment.

\section{INTRODUCTION}

Community Based Tourism (CBT) is a form of tourism that aims to empower people to manage tourism growth and achieve community aspirations related to their well-being, including economic, social and environmental sustainable development. Therefore, CBT does not only involve partnerships between tourism businesses and the community to provide benefits to both, but also involves community (and external) support for small tourism businesses, which in turn are committed to providing support for community projects that improve mutual prosperity.

CBT empowers local communities to determine and secure their socioeconomic future through activities that usually present and celebrate local traditions and lifestyles; preserving natural and cultural resources; and encouraging equal and mutually beneficial host-guest interactions. CBT usually serves niche markets such as adventure tourism, cultural tourism, ecotourism and agribusiness, but refers to local products and services to spread the economic benefits of tourism.

The ASEAN Community Based Tourism Standard (2016) states that community Based Tourism (CBT) is a tourism activity, a community that is owned and operated, and is managed or coordinated at the community level that contributes 
to community welfare through sustained livelihood support and protects sociocultural traditions and resources valuable natural and cultural heritage.

Based on this, CBT must involve and empower the community to ensure transparent ownership and management, build partnerships with relevant stakeholders, gain standing recognition with the authorities, improve social welfare and maintain human dignity, include fair and transparent profit sharing mechanisms, enhance linkages with local and regional economies, respect local cultures and traditions, contribute to the conservation of natural resources, improve the quality of visitor experiences by strengthening meaningful host and guest interactions, and work towards financial self-sufficiency.

The review confirms that the management of tourist attractions is an activity that aims to preserve the local nature and culture. Especially in developing tourism in Indonesia, nature and culture are the main elements that become tourist attractions. The concept of "sustainability" itself is a concept that emphasizes the preservation of various local elements in the local community while still obtaining economic benefits from its existence. Therefore, sustainability also has the orientation of maintenance and care for the existence of nature, society and the scope of their lives. This is more than just maintaining the authenticity of the area and the local community as well as preservation alone.

The concept of sustainability in tourism, specifically the management of tourist attractions, is also an effort to maintain the resilience of local communities of natural funds in their area of residence. Orientation on community development is aimed at maintaining the cohesiveness of the local community, especially when remembering that their territory is the world they know and need to maintain for the sake of environmental and generation sustainability.

The terms "sustainability" and "sustainable development" have appeared in various policy reviews and research. Some literature explains the concept of community-based tourism as a form of effort to maintain and preserve local wealth, especially local nature and culture, both in managing attractions and other activities. Cultural elements are constantly appearing in discussions about 'sustainability' oriented businesses (Bhan \& Singh, 2014; Binti Ramele \& Yamazaki, 2014; Kayat, 2009; Lama, 2013). The term culture can be understood as a variety of artifacts, behaviors, traditions, customs, to the values that underlie a particular practice in culture. Culture itself can be understood as a way of life typical of the local community; daily reality in the social dynamics of the community in an area (Koentjaraningrat, 2015; Robinson \& Picard, 2006). Therefore, the sustainability framework relating to the management of local community-based tourism attractions can cover a variety of things such as the traditions and customs of the local community.

The existence of concepts or ideas about sustainability cannot be separated from concerns over economic development that has a tendency towards Western orientation and the erosion of various local elements to meet market needs, including tourism. Developments, in the framework of globalization, tend to bring ideas and practices that are westernizing the culture of the local community as well as the emergence of a global environmental crisis. The economic development that was accompanied by the development of technology and exploitation of nature brought concern to the increasingly eroded quality of the environment to the quality of life of the local community, especially areas that have local cultural elements 
that are different from Western cultures. This is what then distinguishes the concept of sustainability from development so far.

Brocchi (2008) explains that the concept of sustainability appears as a manifestation of global human awareness of environmental quality and declining social life. Thinking about sustainability views skeptically that both the free market economy and free competition. Within the framework of this concept, environmental sustainability and the survival of local people are considered important to maintain and become a core area in every economic development. In this perspective, various economic actions are applied in the paradigm of diversity, involvement in the experience of local communities, the principles of humanity and justice, and the balance of life (Brocchi, 2008). All of this is inversely proportional to the orientation of the global economy which emphasizes quantity, control, profits, profit-oriented worldview, and monoculture.

In the framework of sustainability, the traditions and customs of the local community are essential and crucial elements in the worldview and ways of life of the people of an area. Considering that customs are an essential element of life, there is not a single human being or community in the world without a tradition. Therefore, in various developments that occur, each individual will always carry the tradition of origin in dealing with various developments. With a sustainability framework that seeks to build the ability to survive and maintain, various changes will be faced with a core orientation on the needs of local communities and the maintenance of natural ways of life (Brocchi, 2008; Soini \& Dessein, 2016).

There are two things that need to be considered in the development of community-based tourism, namely (1) community-based approach by opening the broadest involvement of the Balinese people, through traditional village institutions in the process of tourism development. This participatory approach will encourage dialogue between actors and local residents. Strengthening efforts to empower and enhance the ability of local communities in the process of tourism development, creating a sense of belonging to the development of tourism. Through this process, the development of tourism investment can be sustained without having to be disturbed by open conflict with local residents, and (2) introducing, developing, and expanding the concept of community based tourism (community based tourism). The concept of community-based tourism should pay more attention to the elements of small-scale tourism owned by local communities and provide employment opportunities and economic opportunities to the local community. In addition, the location is scattered and not concentrated only in one place. Its design and activities reflect the character of the local area, promote the preservation of cultural heritage (cultural heritage), do not turn off industries and other activities so that they complement each other, offer quality experiences to tourists and are profitable business activities.

Community-based tourism management has increased the participation of Pakraman Village in the whole process of managing tourism objects which includes planning, implementation and supervision. In addition it can increase the income of Desa Pakraman and its citizens both formally and informally. Community-based tourism has also provided an increase in the ability of Desa Pakraman in tourism development, involving in carrying out tourism activities and tourism managerial abilities which include professionalism and work discipline. 
Community development includes community empowerment, formally supported by the government with the Regional Community Empowerment Agency. In this case the task of the government is only as a facilitator, namely creating conditions that encourage people's initiative in meeting their own needs in solving the problems they face. Informally it appears that efforts to build Balinese society are also efforts from informal institutions such as traditional institutions, religious institutions, the existence of youth associations, and others. Community organizations that are the basis of development are reflected in the existence of the Village Community Resilience Institute and the Village Deliberation Institute. It appears that the government and the population are together trying to improve their communities.

Community-based sustainable tourism development implies that in development, including tourism development in it can be interpreted that the development itself must be sustainable, tourism is also sustainable, and the approach used is community-based. Sustainable development as described by the World Commission for the environment and meeting current needs without doubting the ability of future generations to meet their own needs.

Mowforth \& Munt (1997) in Tourism and Sustainability: New Tourism in the Third World mentions four criteria that are often used for sustainability in tourism, namely: environmental, social, cultural, and economic sustainability.

Ubud with the development of tourism is something to be grateful for all levels of society. The beauty of its natural panorama, art and culture, customs and religiousness of the people of Ubud make Ubud attractive and visited by many tourists from various countries in the world. The atmosphere of Ubud with all its contents is a great potential that is perfect with the integration of tradition and culture which is a strong character of the people of Ubud.

Mandala Wisata Wenara Wana or better known as Monkey Forest is one of the tourist attractions in Ubud, which is managed by local people. Monkey Forest Ubud is a sacred area for locals. For this reason, in the Monkey Forest complex of Ubud, several temples were erected, namely Pura Dalem Agung, Pura Beji, and Prajapati Temple. The Monkey Forest area of Ubud has an area of 12.5 hectares which is inhabited by around 700 monkeys and 186 species of trees. The concept of managing Monkey Forest Ubud can be said to be a reflection of a complex ecotourism. The existence of Ubud Monkey Forest Ecotourism is shaded by the goal of preserving the natural environment and wildlife habitat (mainly long-tailed Balinese monkeys), driving the economy of local communities and embodying cultural values through the implementation of the Tri Hita Karana philosophy. This uniqueness results in an increasing number of tourist visits. The sanctity of the place where there is still a forest in the middle of the settlement, where the ritual ceremony becomes an attraction / the holy place becomes profane (general), and in the process of the ritual ceremony becomes a sacred tourist agenda. So that it becomes an attraction for visitors because of Balinese art and culture, such as dances, kecak, Ramayana ballet, statues, carvings and folklore can be enjoyed.

This qualitative study aims to analyze the community in managing tourism attraction of Mandala Wisata Wanara Ubud (Monkey Forest) through community based tourism. 


\section{METHODOLOGY}

The method of collecting data systematically through field observations by observing and recording the phenomena under study. In this study observations were made to analyse the community in managing tourism attraction of Mandala Wisata Wanara Ubud (Monkey Forest) through community based tourism. Then the method of interviewing the local community is carried out to find out the activities of the community related to their participation in supporting the stages of managing the tourist attraction of the Monkey Forest.

The qualitative data analysis technique used in this study is a qualitative descriptive analysis, that is, analysing and explaining data or events with qualitative explanatory sentences. This analysis was conducted to analyse the results of interviews with local communities and Monkey Forest's management regarding the management of tourist attraction based on community. Data is presented in the form of a description to see the community based tourism in managing Monkey Forest.

\section{RESULT AND DISCUSSION}

\section{Tourist Attractions in Mandala Tourism Wenara Wana (Monkey Forest)}

The Monkey Forest Ubud tourist attraction is one of the attractions that offer natural tourist attractions. The main attractions of Monkey Forest, namely:

\section{a). Flora}

As a tourist attraction, Monkey Forest is a protected forest for hundreds of monkeys that live in it. The Monkey Forest is overgrown with hundreds of trees, including hundreds of years old. Of the hundreds of trees that grow in the forest area there are still rare plants. One of them is Majegau. For the Balinese the "Majegau" is a sacred tree where the hard wood cannot be used as building material. Various types of trees found in the Monkey Forest are an attraction in addition to being a long-tailed macaque residence in Bali.

Monkey Forest is a protected tourism area because this area is a heterogeneous forest area with a total forest area of 73.57 are around 3 hectares used for parking lots and entry counters and the rest is a tourist area. Types of plants found in the Monkey Forest are classified as rare such as; beringin, majegau, pule, binahong, dewan daru, mahkota dewa, sokohasti, ayah wasta and others.

\section{b). Fauna}

Monkey Forest with its dense and green trees really presents coolness, besides the beautiful forest condition, Monkey Forest also has another attraction which is the existence $\&$ behavior of hundreds of monkeys that live in it. Monkey Forest is inhabited by around 300 Bali monkeys which in scientific language is called macaca fascicularis. The Bali tailed macaques are living in different places and each has their own group and leader to show their territory. Because every day they move places so every day their territory changes too.

Monkeys can mate throughout the year but the growth occurs around May to August. Parents of Balinese monkeys are very caring for their babies but sometimes adult male macaques also take care of baby monkeys like female monkeys. Monkey animals in the Monkey Forest are seen and treated like duwe 
(purified animals) by the local community. Visitors to the Monkey Forest attraction can play with the Bali tail macaques that roam around the Monkey Forest forest. The management also collaborated with experts in the field of flora and fauna, namely from the Study of Primate Animals and scientists from several countries that examined the behavior of macaca fascicularis macaques in the Monkey Forest.

In the area there are also some deer that are kept in a cage. The cage is located behind the Pura Dalem. The deer are deliberately maintained in the area to increase the attractiveness of the region and the diversity of existing fauna. The presence of other animals also adds to the beauty of this place such as a few birds that are seen chirping above the branches of trees or just flying through the air, small lizards, squirrels, or some types of butterflies and other insects.

\section{c). Historical Heritage}

Monkey Forest also offers cultural attractions. In the Monkey Forest area there are several temples namely; (1) Pura Dalem Agung, located in the southwest of the forest. This temple is the main temple and is the place where Shiva lives in Hindu religious ceremonies, (2) Beji Temple is located in the northwest region and this temple is arranged with the concept of Tri Mandala which is the Main Mandala in the north and is a place for Deities, Madya Mandala is located in the middle of the temple and there is a pool to ask for holy water (tirta), and Nista Mandala is in the south of the temple and is a place for visitors (pemedek) to purify themselves (to paint), and (3) Prajapati Temple which is located in northeast. This temple is the place where Sang Hyang Prajapati goes. In these temples you can enjoy the unique architecture and carvings that decorate it. Religious ceremonial activities that take place regularly in each of the temples provide an attraction for tourism and the viewpoint of religious traditions.

\section{Tourist Amenities in the Monkey Forest}

Tourist Amenities are necessities for visitors who come. The following facilities are found in the Monkey Forest attractions:

\section{a). Parking}

The management has provided a parking area of 1500 square meters, which is divided into 2 parts, namely in the west and east in order to facilitate road users and avoid congestion. The parking lot can accommodate approximately twenty cars such as: mini bus, combi, jeep and family car.

\section{b). Souvenir Shop}

The visitors can buy various souvenirs around the Monkey Forest attractions that sell various types of crafts in the form of paintings, wood carvings, and various other crafts.

\section{c). Bale Bengong}

Bale Bengong is a resting place for visitors and from this place can enjoy the cool atmosphere of the forest. Bale Bengong provided by the manager also serves as a place to rest for the drivers and tour guides who take the tourists. In the area there is also Bale Bengong which is located in the west and east of Monkey Forest. 


\section{d). Bathroom/Toilet}

The tourist attraction of Monkey Forest provides a bathroom/toilet specially provided for tourists. The management provides four toilets/bathrooms, namely two female toilets and two male toilets located east and west of the Monkey Forest area.

\section{e). Entrance Ticket}

The manager provides three entrance tickets/counters located in the west, east and south for tourists who come from Nyuh Kuning. Ticket Entrance which is located in the east also functions as Tourist Information.

\section{Community-Based Management of Mandala Wisata Wenara Wana (Monkey Forest)}

The management of the Monkey Forest tourist attraction has been carried out by the people of Padang Tegal Village in Ubud since 1971. The Monkey Forest management institution named the Wenara Wana Management Agency is tasked with managing the tourist attraction. But the management is still traditional and only managed by a few people. In accordance with the Regent's Decree No. 973/205/Dipenda/2002, it provides a change in status from a recreational park to an Amusement Park and Management of the Wenara Wana Tourism Mandala Object, which is fully managed by Pekraman Village, Padang Tegal and the Regional Government is no longer interfering in the management of Monkey Forest.

The management of Monkey Forest implements democratic leadership and all problems faced by managers will be taken by a deliberation through holding meetings between traditional villages and the management body which is held routinely every month. In the meeting everything was discussed concerning issues faced by the management and solutions that must be done. In the management of Monkey Forest if there are management officers who are not disciplined in carrying out their duties, the operational chairman has the right to impose sanctions in the form of reprimand or return to the customary village. All parts of the structure of the management of tourist attraction have a responsibility to the operational chairman as the leader in managing this tourist attraction. The tourist attraction management body of Monkey Forest is actively working in developing and improving the quality of services to tourists.

As a result of successfully managing and maintaining conservation in the attraction of Monkey Forest, Padang Tegal Village in Ubud won many awards, including: the Bali Best Brand Award in 2011, won the Kalpataru Trophy from the President of Indonesia in 2012, an environmentally conscious village in Bali in 2013, a village The 2017 Bali Waste Management Pilot Project. From the results of the management of the Monkey Forest tourist attraction by the people of Padang Tegal Village, Monkey Forest was able to reap revenues of more than 65 billion rupiahs and provide tax revenue to the state of around 7 million more rupiahs in 2018.

A total of 17 managers come from the Padangtegal Ubud Traditional Village, which is divided into: (1) 1 manager / manager, (2) 1 administrative \& financial manager, and (3) 15 staff. The officers work at 08.00 Wita until 17.00 Wita using a system of turns (rolling) which is tasked with maintaining the comfort of the tourists and is responsible for the locations they guard. The operational 
chairperson is responsible for providing information at the information post along with the officer who sells the entrance ticket and the administrative \& financial manager is in charge of making financial reports every month. The price of admission charged to visitors is Rp. 80,000 for adult visitors and Rp. 60,000 for visitors aged 3-12 years.

The following is the organizational structure of the Monkey Forest tourist attraction management:

Figure 2.1

\section{Organizational Structure of Monkey Forest Tourist Attraction Management}

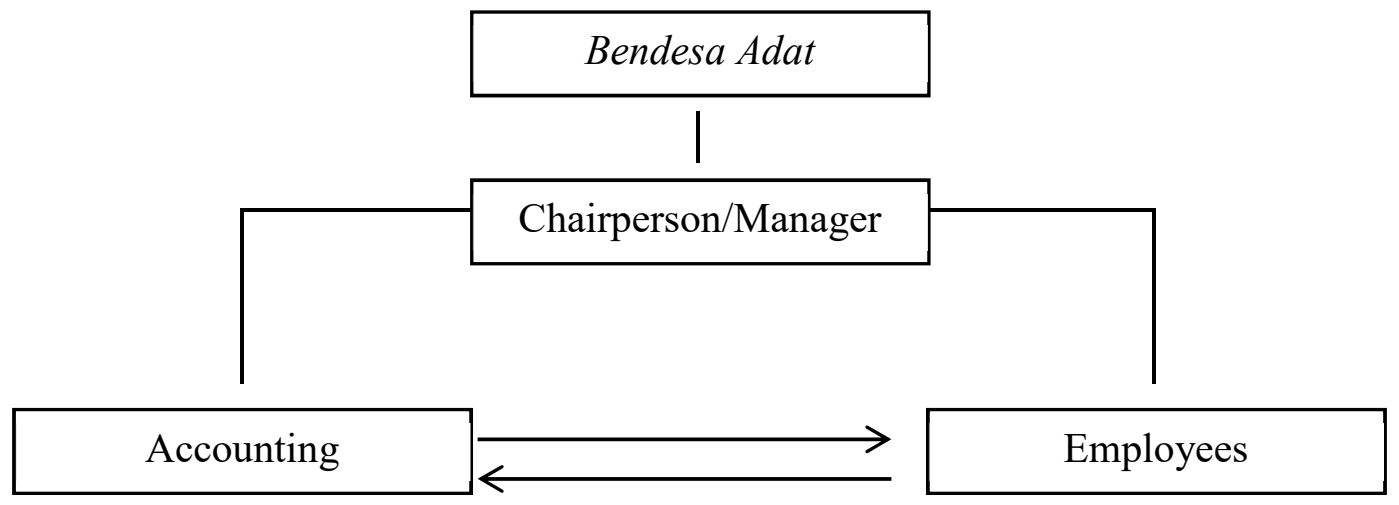

Source: Management of Monkey Forest Tourist Attraction, 2019

Bendesa Adat is responsible for the overall management of the Monkey Forest tourist attraction. The Chairperson or manager is responsible for the custom village for the attraction of Monkey Forest and has the following tasks: (1) maintain the sanctity of the temple in the Monkey Forest environment, (2) maintain the security and preservation of the Monkey Forest environment, (3) enhance and develop human resources in the tourist attraction environment of Monkey Forest, and (4) submit a report on the management of Monkey Forest to the Indigenous Village. The Administration \& Finance Manager is responsible to the operational chair / manager and is responsible for all information and finance in the Monkey Forest. Employees or staff have a duty to maintain the security of attractions and provide services to tourists. In general the duties of the staff are almost the same.

The management of Monkey Forest has carried out several activities to further enhance the maintenance and development of the attraction and facilities contained in the region to tourists, among others:

\section{a. Forest Preservation}

Generally forest preservation is the responsibility of the manager. Forest preservation activities are carried out spontaneously, meaning that if forest damage is encountered or there is a decrease in the number of ape communities, the manager will plant trees and breeding animals to restore their numbers. In addition, the manager maintains the sanctity of the temple contained within the Forest area. 


\section{b. Development of Research Facilities}

The development of this research facility is closely related to the preservation of animals and flora in the Monkey Forest. The construction of a research station has been carried out since 1998 which aims to provide knowledge to outsiders who want to know clearly about flora and fauna and their management. In its development, the manager collaborates with various parties, both for research and captivity of animals.

\section{c. The Construction of a Tourist Park that was built using the concept of Tri Partite Design}

The Monkey Forest area is divided into three zones, namely the core zone (nucleus), the buffer zone and the use zone. The core zone is a temple, the buffer zone is a forest and the utilization zone is built outside the forest area, such as: a park, souvenir shop, parking lot, entrance window, information place. The layout of the park is arranged so as to provide a comfortable and pleasant feel for each visitor. The construction of this tourism park has been started since 2003 and planted various types of plants. The area of this tourist park is about three hectares and is located in the south of the forest. In addition to enjoying the beauty of Monkey Forest, it is hoped that tourists can also enjoy the tourist park facilities found in the forest area.

\section{CONCLUSION}

The management of community-based tourism attractions has increased the participation of local communities in the whole process of managing tourism objects which includes planning, implementation and supervision. The ability of the local community to manage the tourist attraction of Monkey Forest Ubud has strengthened efforts to empower and improve the ability of the local community in the process of developing tourist attraction, creating a sense of belonging (ownership) of tourist attraction and tourism development, maintaining environmental sustainability and improve the economy of the local community.

\section{REFERENCES}

ASEAN. (2016). ASEAN Community Based Tourism Standard. ASEAN Secretariat.

Bhan, S., \& Singh, L. (2014). Homestay tourism in India: Opportunities and challenges. African Journal of Hospitality, Tourism and Leisure, 3(2), 1-5.

Binti Ramele, R., \& Yamazaki, J. (2014). The effects of malaysian homestay program on economy, environment, society, and culture of Malay Kampung: A case of Banghuris Homestay in Selagor. Journal of Architecture and Planning, 79(705), 2433-2442.

Brocchi, D. (2008). The Cultural Dimension of Sustainability. In S. Kagan (Ed.), Sustainability: a new frontier for the arts and cultures (pp. 26-58). VAS Verlag für akademische Schriften.

Kayat, K. (2009). The nature of cultural contribution of a community-based homestay programme. Journal of Tourism, 5(2), 145-159.

Koentjaraningrat. (2015). Pengantar Ilmu Antropologi. Rineka Cipta.

Lama, M. (2013). Community homestay programmes as a form of sustainable 
tourism development in Nepal. Centria University.

Mowforth, M., \& Munt, I. (1997). Tourism and sustainability: Development, globalisation and new tourism in the third world. Routledge.

Robinson, M., \& Picard, D. (2006). Tourism, culture and sustainable development. UNESCO.

Soini, K., \& Dessein, J. (2016). Culture-sustainability relation: Towards a conceptual framework. Sustainability, 8(2), 167. 